\title{
Urban Plans and Conflicting Interests in Sustainable Cross-Boundary Land Governance, the Case of National Urban and Regional Plans in Ethiopia
}

\author{
Genet Alem (D)
}

Citation: Alem, G. Urban Plans and Conflicting Interests in Sustainable Cross-Boundary Land Governance, the Case of National Urban and Regional Plans in Ethiopia. Sustainability 2021, 13, 3081. https:// doi.org/10.3390/su13063081

Academic Editors: Stefan Greiving and Åsa Gren

Received: 7 February 2021

Accepted: 3 March 2021

Published: 11 March 2021

Publisher's Note: MDPI stays neutral with regard to jurisdictional claims in published maps and institutional affiliations.

Copyright: (C) 2021 by the author. Licensee MDPI, Basel, Switzerland. This article is an open access article distributed under the terms and conditions of the Creative Commons Attribution (CC BY) license (https:/ / creativecommons.org/licenses/by/ $4.0 /)$.
Institute for Spatial Planning, School of Spatial Planning, TU Dortmund University, 44227 Dortmund, Germany; genet.alem@tudortmund.de

\begin{abstract}
Policies and rules by which land is governed are influenced by political discourses, and decisions about land can provoke political conflicts. In contexts of vague legal framework governing property right, planning tends to produce inequality and could be observed as a political instrument of marginalization. Nevertheless, spatial planning is indispensable for ensuring sustainable and efficient land governance. In Ethiopia, urban planning is considered unjust, often associated with eviction of rural and urban residents. Indeed, recent experiences had ended up causing drastic political unrest. The paper discusses the institutional gaps in land governance by focusing on two recent urban plans (national and regional) that led to conflicts, undermining sustained socioeconomic development. For this purpose, the research uses qualitative primary and secondary data. Main sources of data are official and legal documents, the literature and interviews. The findings show that current planning practice has produced social and political tensions and conflicts. Hence, urban planning related legal provisions override citizens' right, and vague land policy constrains interregional cooperation in planning and land governance. The paper calls for people focused planning, the revision of policy and legal frameworks to protect socially and economically vulnerable segments of the population and facilitate cross-boundary land governance.
\end{abstract}

Keywords: national urban spatial plan; integrated development plan; and sustainable regional planning; cross-boundary land governance; Addis Ababa; Ethiopia

\section{Introduction}

Spatial planning is one of the important instruments for efficient land management [1,2]. It is a conscious and collective intervention in the nature and form of urban areas to achieve particular social, political, and environmental objectives [1]. Based on trend analysis and actual socioeconomic and environmental demands, it should outline a regulatory framework and standards to guide future spatial development. While protecting the interest of future generations, planning, theoretically, should resolve land use conflicts among different urban land uses, such as residential, industrial, business, and green and water bodies [2-4]. The background of this concept is embedded in the architectural and engineering response to the 18th and 19th century urbanization in Europe [4,5]. Since then, planning, at least in theory, has evolved from rational technocratic thinking to communication using concepts borrowed from social and cultural studies [6-9]. In practice, however, while spatial planning has taken diverse forms mainly in western countries underpinned by national and regional socio-cultural and political contexts [10], it has stagnated at the ethos of past colonial heritage in the Global South [8,9,11-14]. Yet, the core principle of planning remains foreseeing and preparing for the future [2]. Even though it is meant to manage land so that sustainable socio-spatial growth is ensured [2-5], this of course remains a challenge in the context of unprecedented urbanization and the global trend of population growth. 
In Africa, urban population has already exceeded 40 percent of the total population [15]. The trend shows that the population is going to triple in thirty years [ibid.]. This means, for countries such as Ethiopia, 400 thousand additional urban residents per annum in addition to the five million who are already living in dire housing conditions [16]. Furthermore, urban management capacity in most countries of Sub Saharan Africa is still underdeveloped. On the other hand, regional and local urban administrators expect that these urban challenges could be adequately addressed by urban and regional spatial planning. In contrast, the wider population does not share this sentiment. Indeed, planning is often associated with eviction and elite-focused intervention [11,13,17]. Urban planning related laws in most countries in Africa are a continuation of colonial traditions that had made planning an instrument of financial and political power consolidation on one side, and on the other, of creating images based on imported concepts [13]. Some may argue that this is a result of a pathetic view on African urbanization and idealized view of a city as a product of carefully and creatively designed urban form $[4,17,18]$. As a result, several studies on urbanization and urban centers in the Global South, in particular in Africa, focus on deteriorating infrastructure, housing, basic services and poverty in general, violence, and the informal sector [12]. As such, African cities are explained and defined based on their common problems, while their diverse and rich urban traditions are rarely given proper attention. This has contributed to limited resources and debates on the qualities and nature of African cities. At the same time, planning education in Africa continues to depend on imported concepts and models developed in completely different socioeconomic and cultural contexts [14,19]. Planners are trained with planning theories containing universalized assumptions of urban communities and ideal images of a proper city that may be different from realities on the ground [11], whereas residents of cities in Africa, their daily life embedded in their informal networks and socioeconomic activities, are considered as subjects of planning that should be ordered and formalized [11,20]. In addition, planning processes and outcomes in Africa, arguably more than anywhere else, heed to the influence of power. On the other hand, the economically weak and socially excluded parts of the population have limited or no access to influence the planning process nor its outcome. In a context of a weak institutional and undemocratic political system, planning tends to perpetuate state ideology and the interests of politically and economically stronger actors $[11,21]$.

These factors have been the sources of sociopolitical conflicts where the urban poor and peri-urban farmers become the losers of planned re-distribution of resources $[8,13]$. As a powerful instrument that can determine actual and future resource distribution, planning can determine who loses or wins. In principle, planning is expected to work for the benefit of the public and as such should ensure fair distribution of land and land related resources. Yet, as Yiftachel $[22,23]$ noted, planning is also used to control and accumulate capital for those in charge of planning and in control of the process. Consequently, planning can help those with power to take advantage of the poor and the weak, reproducing inequality. Coupled with profit oriented land management system, this can easily perpetuate suspicion and fear regarding its aim. Hence, in a context where poverty is widespread and conflict over resources is intermingled with other socio-political issues, planning tends to be a source of irreconcilable rationalities [11,24-26].

Spatial planning is one of the intervention areas of the FDRE (Federal Democratic Republic of Ethiopia), which is aimed at bridging the gap in managing cross-boundary issues. Ethiopia has a federal government system with a federal government, ten ethnic- based regional states (the tenth is added in 2020), and two autonomous urban administrations. However, this system is currently being challenged by intensifying ethno-political conflicts. The experience of 30 years' ethnic federalism seems to be more of a problem than a solution for deep routed socio-political conflicts. Land governance, within this ethnic federalism, is exacerbating sociopolitical conflicts [27]. It has made dealing with trans-regional boundary issues such as urbanization, environmental protection (water and green resources), and in general socio-spatial developments in peri-urban areas difficult. In addition, interregional 
infrastructure development (road and transport system, electric power development, and distribution network), mandates of managing local and regional resources, i.e., land, and securing overall sustained socio-spatial development have become real everyday challenges. The AAOSIDP (Addis Ababa and the Surrounding Oromia Integrated Development Plan) and NUDSP (National Urban Development Spatial Plan) were launched aiming to bridge the gaps in managing cross-boundary issues. Yet, AAOSIDP had evoked strong opposition, which led to mass protests first in the Oromia region and later triggered the tensions among the government and wider population all over the country $[28,29]$. First, AAOSIDP was officially disapproved by the Oromia Regional Government [29]. Following that, NUDSP failed to get approved by the parliament.

This paper assumes that the public opposition is driven by fear and distrust toward the political authority in control of planning. Therefore, the paper asks, why plans expected to solve problems, cause fear and distrust. With that, it aims to understand the contents of plans, context in which plans are implemented and impacted people and environment. Using the case of planning practice in Ethiopia, the paper aims to contribute to the discourse on conflicting rationalities. The paper also outlines general recommendations, which should be taken into consideration to make planning work in a context where urban realities are loaded with social and ethnic conflicts.

\section{Materials and Methods}

\subsection{Research Design}

The central question guiding the research design is: why do people fear and distrust planning? Based on this question, three specific research questions are derived to guide research design:

- How are people affected by plans?

- Which gaps and contents of current national and regional spatial plans are causing conflicts?

- How does failed planning affect sustainable land management?

In response to these questions, the paper adopts a qualitative research method. Qualitative research helps to understand the reasons behind texts, individual experience, opinions, and other type of documented information describing routines and moments of personal and/or group experiences [30,31]. The study puts emphasis on meanings and processes that cannot be interpreted in numeric values [30]. The paper aims to understand gaps in planning documents, context in which plans have been implemented, and the impact of plans and conflicts hindering their implementation. Consequently, the research is organized into three analytical components: (1) historical and institutional context of planning and plan implementation, (2) actual land use planning, and (3) actual urban development trend. Based on these components and the specific questions, the research is designed to combine qualitative secondary and primary data (Figure 1). The first component, i.e., the context, is analyzed using qualitative secondary data and primary data. This has helped to understand what kind of plans were prepared and in which institutional contexts these were plans implemented. Additionally, qualitative primary data are used to analyze the impact of these plans on families and individuals. The second analytical component, land use plans, are the plans that provoked wider public opposition and as a result were canceled, in the case of AAOSIDP, and halted, in the case of NUDSP. The third analytical component is the actual trend of urban development in the peri-urban areas. The impacts of conflicts and failure in implementing plans guiding cross boundary land management are analyzed using the case of Addis Ababa and Oromia Regional Government (ORG). The paper, hence, analyzes the consequence of failed plan implementation on the peri-urban land management. 


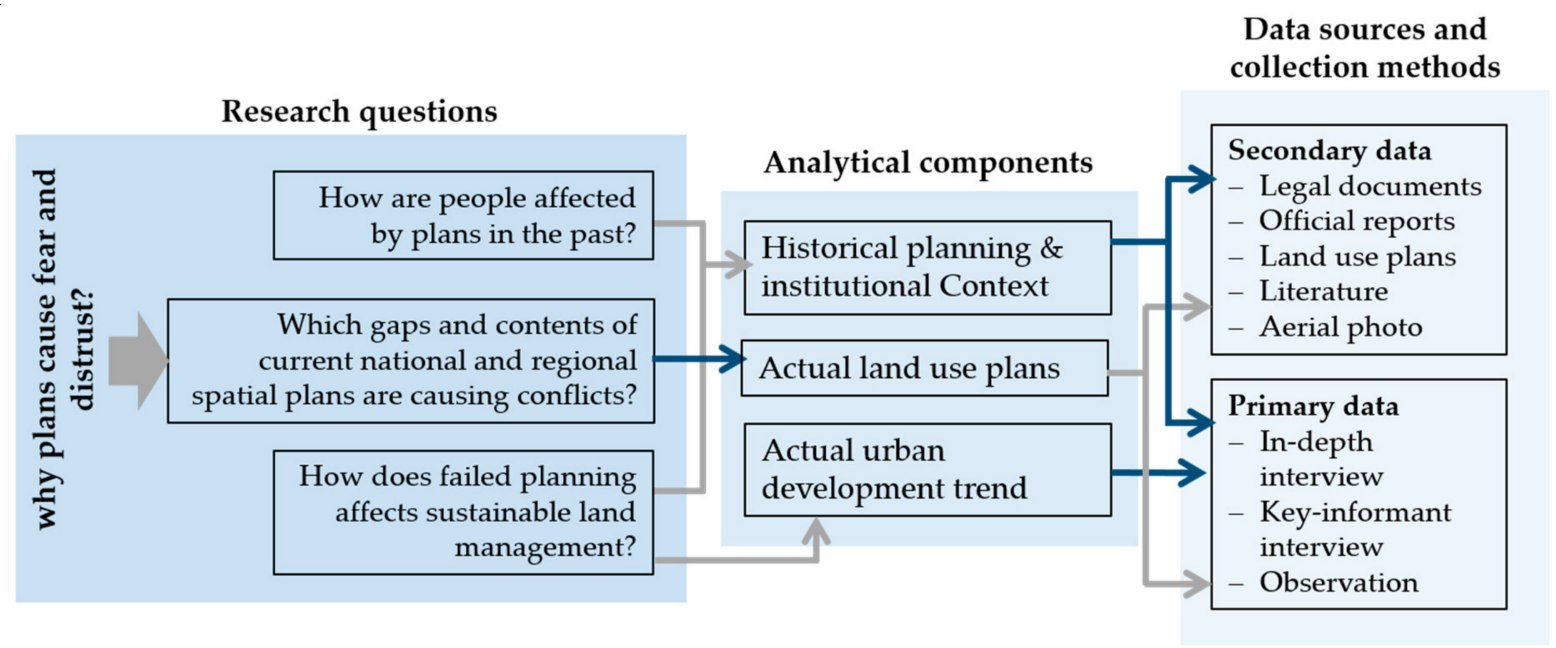

Figure 1. Research design. Source: Author.

\subsection{Historical Planning and Institutional Context}

The qualitative data used to analyze historical planning and institutional context are official reports, land use plans, documents and literature on development policy and program, as well as legal provisions, which have guided land management in general and, in particular, use and ownership of land. Key-informant and in-depth interviews are also used to collect data on planning process and impact of plans. Data from key informant interviews are used to complement and corroborate secondary data. At the same time, to understand impacts of plans on people, in-depth interviews are made with families and individuals who were affected by land use planning. Key-informant interview has provided additional data on opinions of regional authorities and conflicts in the role and mandates of different level of governments. The interview has revealed how sensitive issues related to ethnic federalism have created difficulties and misunderstandings among individual planners, representatives of local and regional authorities, and other stakeholders. The secondary data have shown problems related to public land ownership, land expropriation, and an economic growth focused planning approach.

Six key-informants who were involved in the preparation of the last three master/structure plans $(1986,2002,2014)$ and experts who are working as expert, advisers, and head of bureaus at Ministry of Urban Development, Construction, and Housing (MUDCH) were interviewed. The main guiding questions were about steps and process of planning, participated planning agents and stakeholders, and conflicting rationalities from the perspective of the plans and reality on the ground. Selected and summarized data and sources along corresponding analytical components are presented in Table 1.

The other method used to collect primary data is in-depth interview. Through these interviews, data on experiences of individuals and families during the process of eviction and relocation are collected. These data helped to analyze and comprehend, from the perspective of families and individuals, the fear and distrust of urban and rural population toward plans and authorities in control of planning and land management. The interviews have revealed how people felt powerless in face of government decisions to demolish several neighborhoods and evict and relocate residents without giving them choices. Evicted urban residents and farmers are asked to tell their stories about their feeling on the government's decision to redevelop their former neighborhood for investment projects. The informants have also provided information on the process they went through, from the time they were informed about the decision of eviction to the current time while coping with their new life in condominium houses at the periphery of the city (Figure 2). Eighteen informants, six of them evicted farmers, were interviewed. Questions guiding the interview and selected narratives are presented in Table 2. 
Table 1. Sources and selected categorized data along analytical components.

\begin{tabular}{|c|c|c|}
\hline $\begin{array}{l}\text { Analytical } \\
\text { Component }\end{array}$ & Categories of Data (Selected) & Main Data Sources \\
\hline $\begin{array}{l}\text { Historical and } \\
\text { institutional } \\
\text { context } \\
\text { (Secondary data) }\end{array}$ & $\begin{array}{ll}\text { - } & \text { Legal guideline for urban development } \\
\text { - } & \text { Form of land ownership and customary } \\
\text { land tenure } & \text { Legal guideline for setting-up urban } \\
\text { - } & \text { settlements } \\
\text { - } & \text { Public land ownership and custodian } \\
\text { of land } & \text { Expropriation of landholdings } \\
\text { - } & \text { Types and steps of urban planning at } \\
\text { national, regional, and local level } \\
\text { - } \quad \text { Responsibilities of planning agents } \\
\text { - } \quad \text { Key principles-planning: } \\
\text { participation, transparency } \\
\text { - Declaration of settlements: } \\
\text { unplanned/redevelopment } \\
\text { - Urban development framework } \\
\text { - } \quad \text { Priority intervention area of urban } \\
\text { development, priority urban development } \\
\text { intervention areas } \\
\text { Procedures, steps, and process }\end{array}$ & 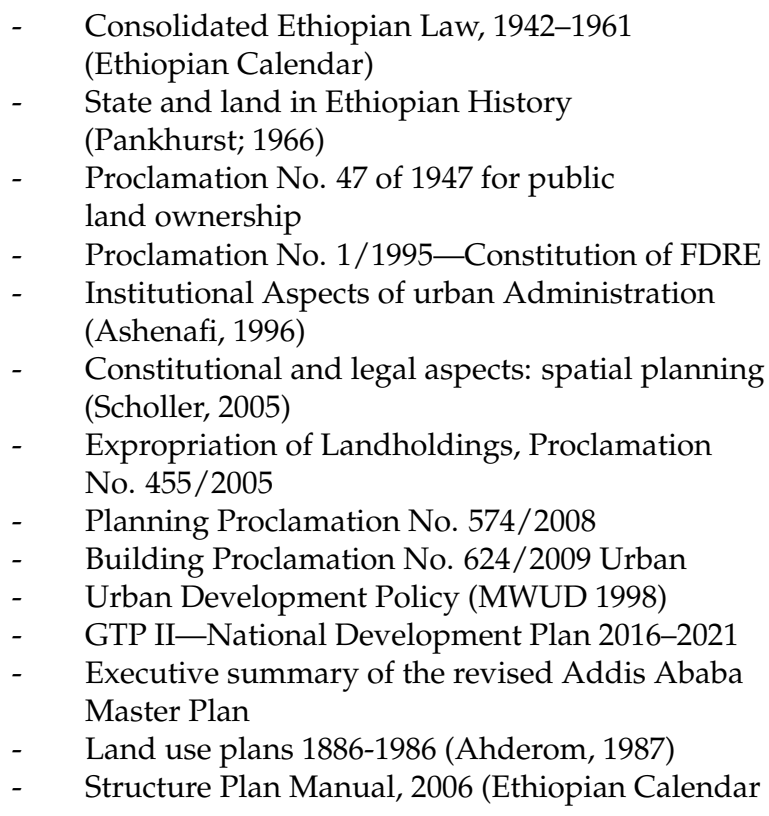 \\
\hline $\begin{array}{l}\text { Historical and } \\
\text { institutional } \\
\text { context } \\
\text { (Primary data) }\end{array}$ & $\begin{array}{ll}\text { - } & \text { Priority urban development } \\
\text { intervention areas } \\
\text { - } \quad \text { Procedures, steps, and process } \\
\text { - } \quad \text { Conflicts among local, regional, and } \\
\text { national mandates } \\
\text { - Impacts: eviction, relocation, } \\
\text { env'al. degradation }\end{array}$ & $\begin{array}{ll}\text { - } & \text { Experts who worked on former land use plans } \\
\text { - } & \text { Experts involved in regional and national spatial } \\
\text { urban plans } \\
\text { - } \quad \text { Evicted and relocated families } \\
\text { - } \quad \text { Aerial photo and actual peri-urban development }\end{array}$ \\
\hline $\begin{array}{l}\text { Actual Land use } \\
\text { plans } \\
\text { (secondary data) }\end{array}$ & $\begin{array}{ll}\text { - } & \text { Types and steps of urban planning } \\
\text { - } & \text { Responsibilities of planning agents } \\
\text { - } & \text { Key principles-planning: participation, } \\
\text { transparency, accountability, } \\
\text { socio-environmental safeguarding } \\
\text { - } \quad \text { Hierarchy and network of national } \\
\text { urban centers } \\
\text { - } \quad \text { Existing and emerging urban } \\
\text { agglomeration areas } \\
\text { - Urban-rural linkage and key urban } \\
\text { development functions }\end{array}$ & $\begin{array}{ll}- & \text { NUDSP } \\
- & \text { AASOIDP } \\
- & \text { Newspaper articles and blogs on plans and } \\
& \text { provoked conflicts }\end{array}$ \\
\hline $\begin{array}{l}\text { Actual Land use } \\
\text { plans } \\
\text { (primary data) }\end{array}$ & 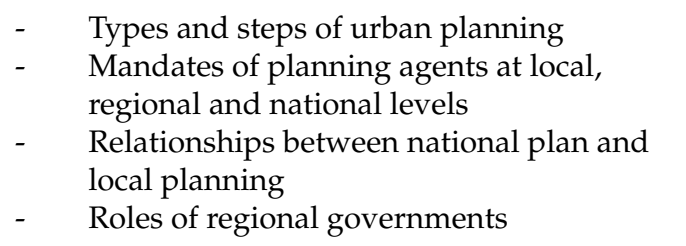 & $\begin{array}{l}\text { Experts who were part of the process in } \\
\text { commission and approval of the national } \\
\text { urban plan } \\
\text { Experts involved in the preparation of the plan }\end{array}$ \\
\hline $\begin{array}{l}\text { Actual urban } \\
\text { development trend } \\
\text { (primary data) }\end{array}$ & $\begin{array}{l}\text { - Urban development dynamic in } \\
\text { per-urban areas } \\
\text { - Water bodies and green/forest areas in } \\
\text { per-urban areas }\end{array}$ & $\begin{array}{ll}- & \text { Aerial photos } \\
\text { - } & \text { Observations }\end{array}$ \\
\hline
\end{tabular}




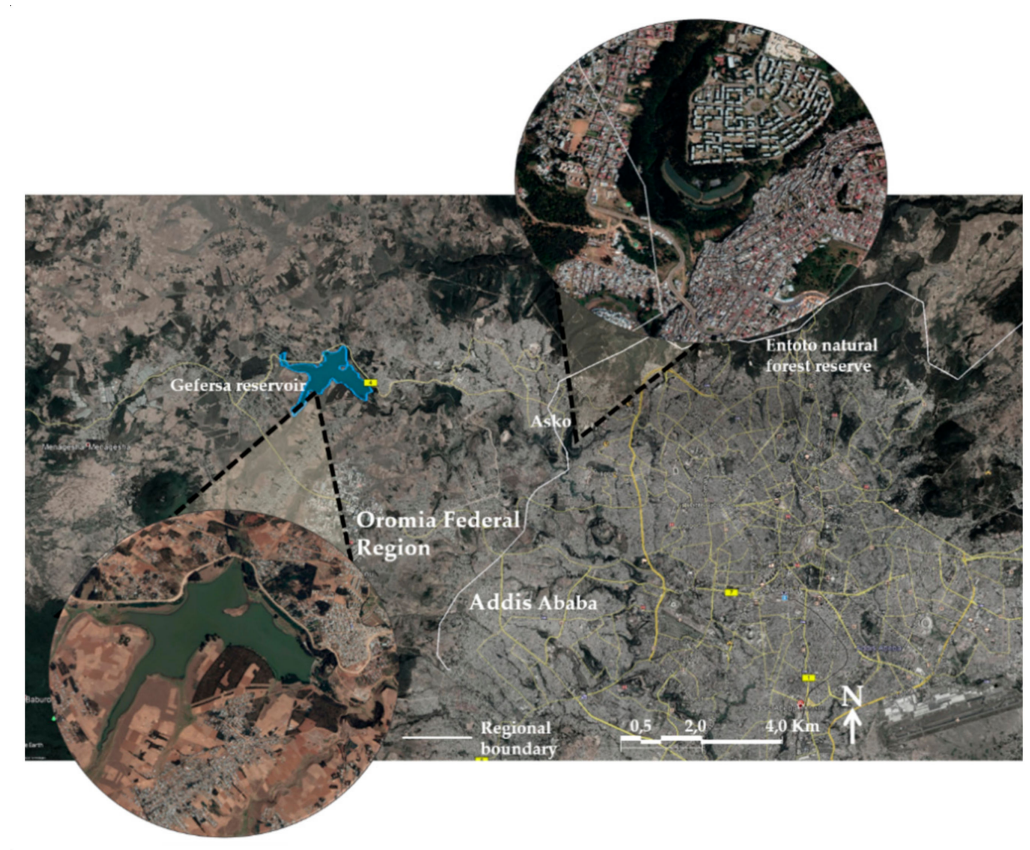

Figure 2. Urban expansion along regional boundary. Source: Author based on GoogleEarth, 2021.

\subsection{Actual Land Use Planning}

The second analytical component is the actual land use planning. These component is analyzed using the cases of two plans: NUDSP (National Urban Development Spatial Plan) and (2) AAOSIDP (draft of the Addis Ababa and surrounding Oromia Integrated development plan). Consequently, the main source of data is the mentioned plans. Yet, primary data through key-informant interview are collected to corroborate and complement the data from the maps and official reports. Similar to the former analytical component, key-informants were asked their experience and personal opinion on steps and process of planning, participated planning agents and stakeholders, and conflicting rationalities from the perspective of plans and reality on the ground. In addition, it was important to find out experts' views on conflicts related to cross boundary land management and ethnic federalism. These group of informants were also asked to explain the situation during the presentation of the national plan to the parliament and the regional plan to the public (see Table 1).

\subsection{Actual Urban Development Trend}

The third analytical component is the actual urban development trend at the periurban area of Addis Ababa. The data for this analysis were collected from onsite observation and aerial photos. As it is discussed in the introduction, the regional plan, i.e., AAOSIDP, and national urban spatial plan, i.e., NUDSP, are on hold, and in particular, the regional plan is officially canceled. Therefore, in addition to the data required to understand the plans and their limitations, it is important to analyze the impact of urban expansion with adequate spatial plan to manage peri-urban areas divided by regional boundaries. Therefore, data are collected through on-site observation and aerial photos. These data show that urban expansion is getting intensified along the main roads and transport lines linking Oromia Federal Region and Addis Ababa (Table 1 and Figure 2). Both formal and informal developments are encroaching farming and forest areas. Steep hills and riversides, which are part of protected green and blue infrastructures in the former and the actual regional plan (AAOSIDP), are mostly covered by all kind of developments. Water reservoirs serving Addis Ababa and the surrounding region are surrounded by flourishing informal settlements and real estate developments. In particular, the edge of Gefersa drink water reservoir in Oromia region is mostly covered by informal settlements. 
Table 2. Relocated urban residents and farmers and selected narratives.

\begin{tabular}{|c|c|c|}
\hline Informants & $\begin{array}{l}\text { Selected Questions } \\
\text { (Key-Words) }\end{array}$ & Key Statement \\
\hline $\begin{array}{l}\text { Urban Group } 1 \\
\text { (Three informants evicted } \\
\text { from Piazza area, city center) }\end{array}$ & \multirow{2}{*}{$\begin{array}{l}\text { Feelings on relocation; } \\
\text { encountered problems at } \\
\text { the relocation site }\end{array}$} & $\begin{array}{l}\text { I am happy to have this condominium. Actually, it is not that far } \\
\text { from our former place in city center area... The only problem is } \\
\text { social life. Most of our neighbor and relatives did not have luck } \\
\text { like us. } \\
\text { We rent the apartment for other people and live here in the city } \\
\text { center in much smaller room with the whole family. It is too far } \\
\text { from my work place and cannot afford to pay for the transportation. }\end{array}$ \\
\hline \multirow[t]{2}{*}{$\begin{array}{l}\text { Urban Group } 2 \text { (Two } \\
\text { informants from } \\
\text { Tekleheimanot area, } \\
\text { city center) }\end{array}$} & & $\begin{array}{l}\text { I am very sad; Piazza was not only my home, it was also my work } \\
\text { place. Now, I don't have customers here and have to pay the credit } \\
\text { for the condominium. } \\
\text { I used to support my siblings, but now they cannot even live with } \\
\text { me. I have to rent the bed room to pay my credit. I lost my job in } \\
\text { the city center. }\end{array}$ \\
\hline & Life in new neighborhood & $\begin{array}{l}\text { I spend } 3 \text { to } 4 \text { h every working day to commute between work and } \\
\text { home. Half of the way to work I have to walk; I cannot afford to } \\
\text { pay for mini-buses all the way to the center. } \\
\text { If I get sick, I don't know what to do. I have credit to pay and try to } \\
\text { survive with pity-tread. }\end{array}$ \\
\hline $\begin{array}{l}\text { Urban Group } 3 \text { (Five } \\
\text { informants from } \\
\text { Betemengist area, inner city) }\end{array}$ & \multirow[t]{2}{*}{$\begin{array}{l}\text { On the provision of } \\
\text { information and support } \\
\text { from the government }\end{array}$} & $\begin{array}{l}\text { I cannot say it was an information. They just say we have to go and } \\
\text { we refuse to go, but our house is now gone, destroyed! } \\
\text { There was this guy, who came to discuss with us. We asked him if } \\
\text { we get help at least for transporting our furniture. He just said he } \\
\text { has nothing to do with that. He is sent to advise us how we could } \\
\text { organize ourselves and get credits. }\end{array}$ \\
\hline $\begin{array}{l}\text { Urban resident } 4 \text { (Two } \\
\text { informants from Filwuha } \\
\text { area, inner city) }\end{array}$ & & $\begin{array}{l}\text { The government did not even help us to cover the cost of } \\
\text { transportation. It was so expensive for me to pay for the truck, } \\
\text { which took our furniture to Jemu Condominium }\end{array}$ \\
\hline \multirow[t]{2}{*}{$\begin{array}{l}\text { Farmers (Six members of } \\
\text { former farmers association } \\
\text { for self-help job creation } \\
\text { initiative, Bole-Bulbual, } \\
\text { South-East peri-urban area) }\end{array}$} & Process of relocation & $\begin{array}{l}\text { We have no right to ask why we should move from our } \\
\text { neighborhood. They only say that the land is needed for } \\
\text { the development. } \\
\text { We complained to the government and the Woreda (local urban } \\
\text { administration) have us organized in an association. They say we } \\
\text { have to organize in association so that they could help us. } \\
\text { Me and my family are the poorest of the poor, I can't even afford to } \\
\text { live in the condo. I need the rent to pay my credit. }\end{array}$ \\
\hline & $\begin{array}{l}\text { Coping with the } \\
\text { situation now }\end{array}$ & $\begin{array}{l}\text { We have this land from the Woreda. They say we could get fee from } \\
\text { parking. But now there are other former farmers claiming this same } \\
\text { land and we don't know if we could keep it. }\end{array}$ \\
\hline
\end{tabular}

Source: Author.

\subsection{Sampling and Data Analysis}

As qualitative research, the sampling is purposive. Secondary data are obtained from literature and documents on historical and institutional context of spatial planning, and the different proposed master and structure plans. Purposive sampling is used to identify and select key-informants according to their expertise in policy and spatial planning. For key-informant interviews, six experts with 15 to 30 years of experience in expert and leadership positions in Ethiopia are selected and interviewed (see Table 3). Some of these key-informants were staff of the project office, who prepared the regional plan, i.e., AAOSIDP. The other group are policy and spatial planners, who advised Federal Ministry of Urban Development, Housing, and Construction (MUDHC) in preparation of tender and follow up of the national urban plan. Informants for in-depth interview are selected combining purposive and snowball sampling methods. Purposive sampling is used to identify informants according to their personal experience of eviction and relocation 
(Figure 3), while snowball method is used, first, to use contacts in Addis Ababa to find and establish contact with informants. Secondly, already identified and contacted informants are used to connect with other informants.

Table 3. Key-Informants: profession, projects, organization, and position in their organization.

\begin{tabular}{|c|c|c|c|}
\hline Inf. & Profession & Project/Organization & Position \\
\hline \multirow{2}{*}{1} & \multirow{2}{*}{ Economist/Planner } & The revision of Addis Ababa Master Plan, 2003 & Expert \\
\hline & & Addis Ababa and Oromia Special Zone Integrated Development & team leader \\
\hline \multirow{4}{*}{2} & \multirow{4}{*}{ Architect/planner } & Addis Ababa Master Plan, 1986 & team leader \\
\hline & & The revision of Addis Ababa Master Plan, 2003 & Project manager \\
\hline & & $\begin{array}{l}\text { Addis Ababa and Oromia Special Zone Integrated Development } \\
\text { Plan (AAOSIDP), } 2014\end{array}$ & Project manager \\
\hline & & National Urban Development Spatial Plan (NUDSP), 2016 & Adviser/consultant \\
\hline \multirow{2}{*}{3} & \multirow{2}{*}{ Urban and regional planner } & Amhara Urban Development Housing and Construction Bureau & Bureau head \\
\hline & & Ministry of urban development and construction & Bureau head \\
\hline 4 & Urban and regional planner & Ministry of urban development and construction & Adviser \\
\hline 5 & Economist & Ministry of urban development and construction & Bureau head \\
\hline 6 & Economist & Ministry of urban development and construction & Expert \\
\hline
\end{tabular}

Source: Author.

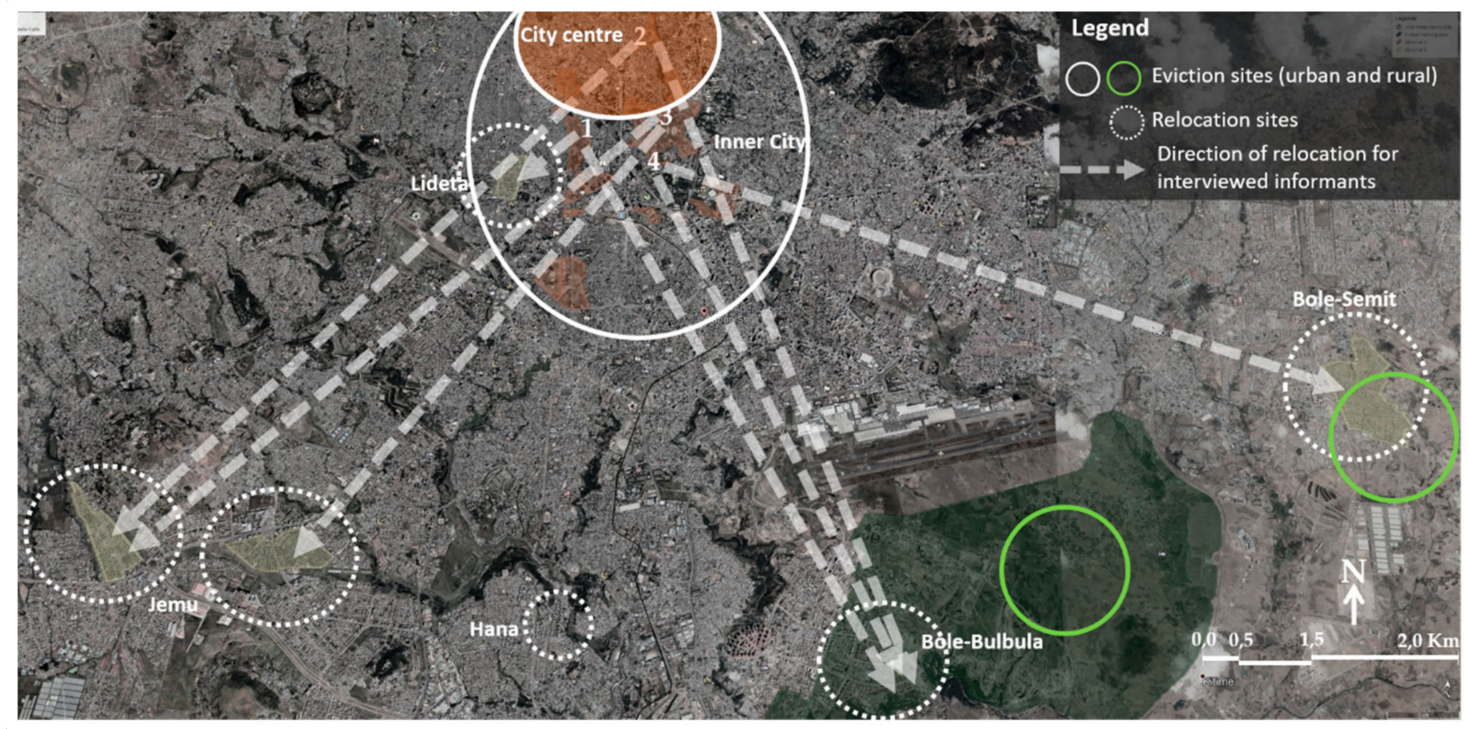

Figure 3. Former residence and relocation sites of informants. Source: Author.

Content analysis is the main method to analyze both secondary and primary data. Secondary and primary data are classified and coded based on the analytical components and specific questions. These data, together with the ones obtained from aerial photos and observation, are condensed, coded, and categorized along specific questions. Table 1 presents sources and selected categorized data along analytical components).

\section{Results}

\subsection{The Contex of Land Governace in Ethiopia}

Even though the legal framework governing land ownership has been vague and complex throughout the history $[32,33]$ of the country, there is one thing that seems to have remained constant- - the principles guiding land ownership. Despite basic changes in current and past sociopolitical contexts, land remains public property regardless of who exactly has custody of land. The Emperor before 1975 and Central Government during the socialist era (1975-1991) were the custodians. The 1993 constitution has decentralized this power to the regional governments. 
To date, there is no comprehensive land policy in Ethiopia, which facilitates efficient and sustainable land management. Within this context, land ownership has always been a political question. Back in the imperial period, it was obvious that land was a means to secure political power and payment for services delivered directly to the emperor, church, or any other royal or military officer entitled to administer or govern over particular pieces of land. For instance, emperors used to provide fief land to key regional lords to strengthen their influences. Yet, fief land ownership was not fixed to a particular location [32-34]. Important officers with fief land right were kept moving from one place to the other so that they did not have enough time to make a bond with the respective local people. Even though there were tenure types such as "Erist" - communal land right system in North Ethiopia - and private land ownership in the late 19th century, the Emperor remained until 1975 the custodian of all land in the country. This meant the sovereign could theoretically revert at any time the condition in which individuals or groups held land tenure $[32,34,35]$.

The Ethiopian revolution in 1975 was driven by a slogan "land for the tiller". The revolution led to the end of the Ethiopian monarchy and the nationalization of, among other things, all land and properties, which were rented for residential and business purposes. As of Proclamation No. 31/1975 and No. 47 of 1975, all lands become public property, and citizens were allowed to access strict size of land through usufruct right [36,37]. Tenants conceptually became owners of the land they tilled, while urban residents in rented houses were freed from their obligation toward the landlords. The tenants were allowed to maintain and use the houses or shops by paying considerably less rent to urban authorities or a government agency in charge of the nationalized properties [38]. At first glance, farmers were tilling their own land, and urban dwellers could access affordable houses and plots for residential purpose. In reality, the population became tenants of the government and, with that, politically dependent [33]. In particular, most of the urban population did not have the economic capacity to build, although urban land was accessible with minimal land tax payment. Hence, for the most part, the urban population was the tenant of the government in already crowded and dilapidated nationalized houses [39].

The principle of the above discussed land ownership system has persisted, despite the collapse of the socialist government and change of the system to market economy in 1991. The economic reform and land management has opened up the access to land for private investment. Yet, land remains under public ownership. Indeed, the 1991 constitution in Article 40 (3) has promulgated that "the right to ownership of rural and urban land, as well as of all natural resources, are exclusively vested in the State and in the peoples of Ethiopia. The constitution clearly states that land is a common property of the Nations, Nationalities and Peoples of Ethiopia and shall not be subject to sell or to other means of exchange" [40]. Since then, the Federal States, through Article 52 (2) of the above proclamation, have become custodian of land and other natural resources within their jurisdiction. The lease policy, which was enacted in 1993 has facilitated a kind of tenure security for up to 50 to 99 years depending on the type of investment [41]. This has made possible that the principle of socialism, i.e., Marxist land theory, continues to underpin land ownership in Ethiopia, while lease policy has commodified land and made it accessible for the highest bidder under lease contract. This, at the same time, has intensified speculation of land, marginalizing the urban poor and rural farmers. In addition, citizens remain dependent on the government in accessing affordable land and housing. This has permitted strong control of the governing party on social and economic development of individuals and groups, creating a conducive environment for political oppression [32,33].

\subsubsection{Urban Planning in Ethiopia, a Tradition in the Making}

Urban planning as a professional practice in Ethiopia is a recent phenomenon. Yet, there were professions and offices related to land and general urban management issues. For instance, the highest authority of a particular province, a region or the country used to award titles, such as "Mehandis" for a municipal engineer, "Kentiba" for a Mayor, "Neggadras" for administrator of custom posts and commercial districts, and "Bejirond" 
for royal treasurer and administrator of chartered land. In addition, there were, though fragmented, several legal provisions concerning urban land administration and land use $[35,42,43]$.

In the modern history of Ethiopia, the legal provisions related to municipal administration of urban centers were enacted in 1930s. These provisions laid the framework for municipal administration and taxes related to urban land development [44]. Later in 1942, Proclamation No. 1 of 1942 has acknowledged local urban governance through the legal establishment of municipalities with their own elected council all over Ethiopia. The municipalities had rights and responsibilities to control and guide urban development activities and the provision of urban infrastructure and amenities [45]. Yet these proclamations do not refer to spatial planning or the need for planning consent to guide urban development at all. For instance, paragraph 4 (3) of Proclamation $4 / 7$ of 1937 EC (Ethiopian Calendar), with regard to construction permit, states that any construction activities to build, renovate and demolish buildings must get the consent of the municipality. The role of the municipality is to evaluate the individual proposal so that it does not affect the public health and security [45].

Except for some conceptual provisions in old legal documents such as "Kibre Negest" and "Serate Mengest" [46,47] and the conceptual land use map called "Taitu Master Plan" for Addis Ababa [48], there so far is no evidence of spatial plans or the tradition of preparing one. Hence, in this paper, the five-year Italian occupation is considered the period where modern spatial planning is introduced.

\subsubsection{Introduction and Evolvement of Urban Planning Tradition in Ethiopia}

The five-year Italian occupation of Ethiopia could be taken as the beginning of modern urban planning in the country. At the time, there were still no obvious planning institutions with legal status to provide guidelines and set the roles of actors in planning and implementing urban spatial plans. The aim of the spatial plan, at this period, was a politically motivated program to build standard European towns and, in particular, to make Addis Ababa the center of Italian colonization in East Africa [43,49]. With this in mind, the Italian authorities commissioned the first urban spatial plan, i.e., master lan, for important Ethiopian cities. These plans brought new forms of settlement pattern to the traditional and organic layout of urban centers in the country [48]. In addition, the racial segregation following this plan was, perhaps, the first organized eviction of urban residents in Ethiopia.

Two decades after the Italian occupation, planning in Ethiopian cities became an issue. Until then, urban "development" was dealt with by Public Health Proclamation of 1942 and 1947, as the proclamation covered matters related to land use control [50,51]. Nevertheless, this proclamation can be considered the first legal provision enacted to guide urban development. Meanwhile, Emperor Haile Selassie had the ambition to make Addis Ababa the "beautiful capital city" that would serve not only Ethiopia, but also the whole of Africa as the center for the then established OAU (Organization for African Unity). Therefore, he commissioned several foreign architects and planners to prepare a Master Plan for Addis Ababa and sixty municipalities all over the country from 1946 to 1965 [27-29].

The 60s were the formative years of urban development in Ethiopia. For instance, in 1960, the "Civil Code" was enacted, and town planning was integrated to the economic and social development plan. In addition, in 1960, the Central Statistical Agency (CSA) was established. This was indeed a milestone that permitted monitoring and evaluation of urban growth through demographic indicators [43]. The various master plans realized in this period, including the one prepared for Addis Ababa by the French Mission for Urban Studies and Habitat, could not make any noticeable impact on the development of the urban centers. However, there was no matching institutional and legal provision facilitating the implementation of such plans at the time. Indeed, the first municipal engineers, which 
were expected to support the implementation of spatial plans in central government and municipal levels, were admitted to the newly established planning school in 1971 [43].

The Ethiopian revolution in 1975 brought a drastic change in urban land development, as Socialism was the new state ideology. Land and extra urban houses were nationalized, and private investment was halted. However, the urban plans that were prepared in this period were not much different from the former ones. Similar to the Italian and imperial master plans, a European architect, this time from the Eastern bloc, was commissioned to prepare the first socialist master plan for Addis Ababa [52]. It was first in 1986 that local architects and municipal planners took part in planning. Nevertheless, there was no considerable change in the concept of the plan. At the same time, the institutional framework supporting spatial planning was taking shape through a proclamation to establish the Ministry of Urban Development and Housing [42]. Until the establishment of NUPI (National Urban Planning Institute), which was later on renamed Federal Urban Planning Institute or FUPI in 1987, the ministry was entrusted with all responsibilities related to urban development [42].

The establishment of NUPI brought about considerable change in the culture of spatial planning in the country. The aim of establishing NUPI was to enhance urban studies, planning, and training of manpower needed for plan preparation and implementation [50]. It had the responsibility of supporting the Ministry in technical matters related to urban planning [50]. The planning practice was also progressing to a different level. With the 1986 Addis Ababa Master Plan, spatial planning has extended its domain from the urban to regional level. Planning for the metropolitan area of Addis Ababa with its several urban centers and rural areas became the subject of spatial planning. Most importantly, planning beyond the urban administrative boundary became a new standard [48]. In addition, the 1986 Master Plan extended its domain from physical to socio-spatial level. All this has led to some kind of uniformity in urban land use planning and has contributed to set up procedures as well as standardize land use planning in Ethiopia [42].

Though the 1986 Master Plan was a milestone for development of spatial planning in the country, similar to most of its predecessors, the implementation was not successful. It was already ten years old by the time the plan was approved. In addition, the plan had unrealistic proposals, such as the redevelopment of most of the oldest settlement into a modern CBD (central business district). In the meantime, Addis Ababa continued to grow haphazardly and informally. Until the establishment of an Office for the Revision of the Addis Ababa Master Plan (ORAAMP) in 1999, the attempt made to make use of the 1986 Master Plan to guide and control the spatial development of the city mainly succeeded in prohibiting residents from constructing or rebuilding on legally occupied land. Indeed, an informant, who was working for Addis Ababa City Administration in the 1990s, noted that residents in the inner city of Addis Ababa and others on the periphery were not given building permits to build or rebuild their houses, as the master plan had reserved, in some cases, large tracts of land for services, or functions that were not residential. At the same time, residents in the inner city were living with fear of relocation. Informants, who were relocated from the inner city of Addis Ababa to newly developed condominiums in Jemu and Bole-Bulbula (Figure 3), recall their fear in the 1990s, which had culminated in the wave of eviction that began in 2000s (informants).

In late 1990, it became clear that former plans had failed and there was a need for a paradigm change to make planning work. Consequently, the planning team commissioned to prepare the terms of reference for the revision of the 1986 Master Plan came up with an approach that was supposed to facilitate the effectiveness and compatibility of the plan to changing policy environment and the development agenda of the city [interview; 48]. Ever since, the terms "master" or "comprehensive" plan have disappeared from planning dictum, if not its practice, and the term used has become "structure" plan. The structure plan is assumed to introduce flexibility for accommodating existing urban fabrics and urban growth by limiting its structuring and land use frameworks on key spatial components, such as green infrastructure, main road and transport networks, markets and city centers, 
and main social and municipal facilities. In addition, the plan introduced a new form of land use, i.e., mixed land use, by taking into consideration the reality in Ethiopian cities and conditions in which compatibility of different land uses could be checked [50]. The plan included a component that identified "strategic development areas" (Figure 4). These were, principally, areas with socioeconomic development importance and with detailed land use and urban design studies thereof. Moreover, the plan made recommendations for necessary policy instruments, legislations, regulation, and standards by taking into consideration urban rural linkage and the role of Addis Ababa and other regional centers at a national and international level [50].

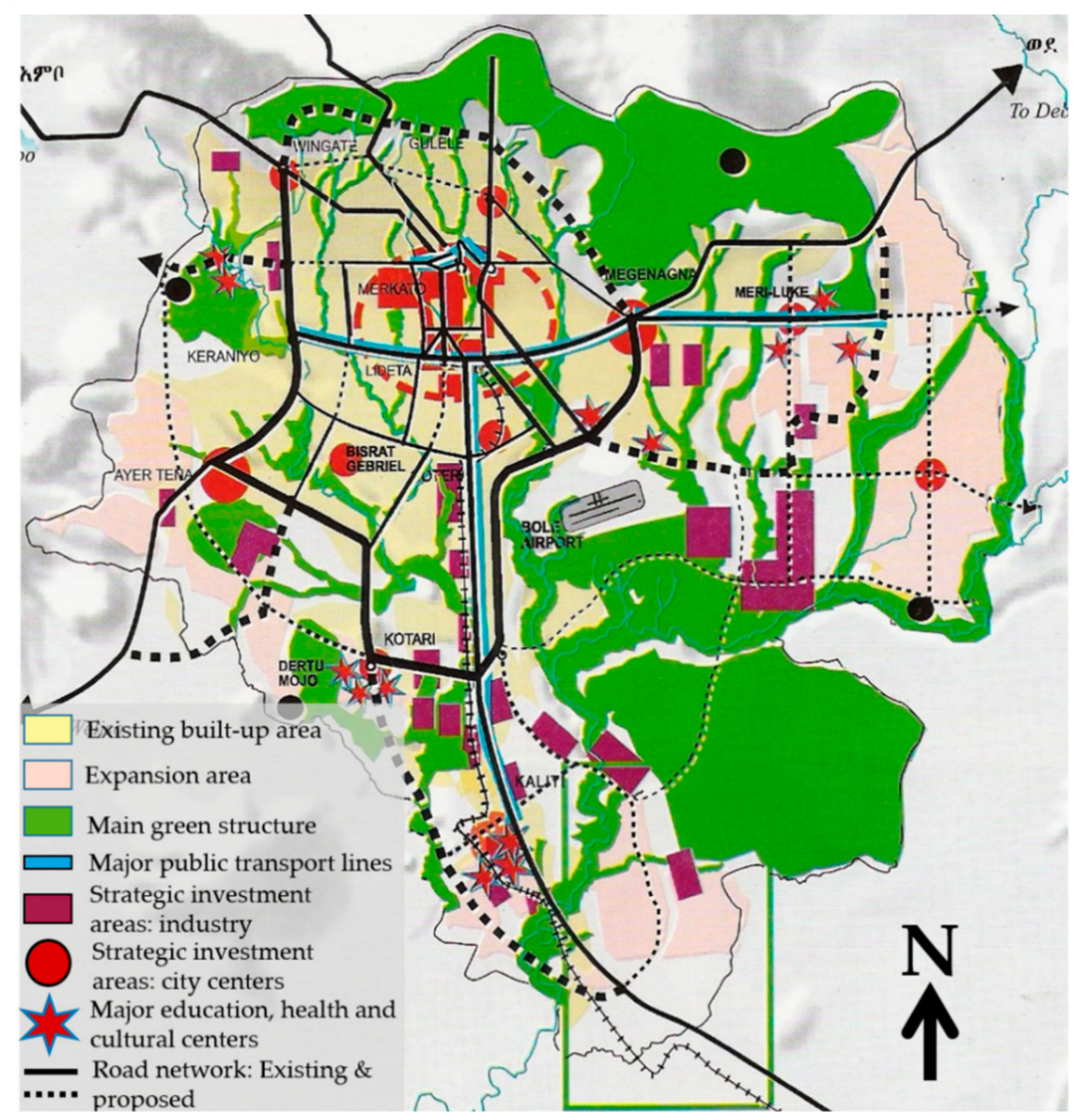

Figure 4. Addis Ababa Structure Plan, 2002-2012, Source: ORAAMP [48].

Urban planning is now integrated into the country's tradition of urban management. Nonetheless, it has kept its original character: technocratic and elitist. Its introduction was linked to the short-lived attempt at colonialism, and as such, it was a symbol of colonial power to order and subjugate the natives, as well as to build a European city $[49,53]$. The later was imbedded within the modernist planning practice of the imperial era. It is observed that there are some methodological changes to facilitate public participation in current urban planning [48]. Unfortunately, an urban form that requires eviction and relocation underpins the current planning strategy. Most importantly, unlike the past, the interventions are now real. In Addis Ababa, the original organic and historical settlements of the inner city are destined for radical redevelopment projects, resulting in the demolition and clearance of several neighborhoods. Though the older settlements have several problems, the focus of redevelopment has been mainly on the urban form, which, from the perspective of elitist planning, should be modern and profitable. In reality, the projects have little to do with the residents of these settlements and the farmers in peri-urban areas. 
The plans primarily focus on in increasing private investment in real estate projects (Informants; [54]). Indeed, such practices are supported by decrees such as Proclamation No. 455/2005 for expropriation of landholdings for public purposes and payment of compensation and building, and urban planning proclamations No. 624/2009 and n = No. $624 / 2009[55,56]$. The first of these proclamations makes any kind of opposition against expropriation of landholdings illegal and give precedence to land use planning over the need of residents [55]. With the provision of Article 15(2), the proclamation makes any other laws inapplicable. That means residents cannot use civil laws for refusing relocation and demolition of their property regardless of whether their property is constructed according to the provision of laws or if they are legal tenants of government owned houses. In addition, the urban planning and building proclamations provide standards that ignore the reality of residents. In particular, proclamation No. 624/2009, in its objectives (Article 4) and principles (Article 16), underlines planned urban centers and economic growth, respectively [56]. This automatically declares older settlements, for instance in Addis Ababa, as unplanned, and hence, areas for redevelopment projects. Already, several historical neighborhoods of Addis Ababa have been demolished, and others will follow (informants; [54]). In fact, this is in contradiction to the principles specified under Article 5 of the planning proclamation. The article lists participation, transparency, accountability, and safeguarding the community and environment as key principles. Yet, it is not clear how the opinions of the community or the society could make a difference when the expropriation law removes all the rights to oppose eviction. Families were evicted from the neighborhood where they were born and grown and where their parents, relatives, and friends used to live. Their stories show how weak and helpless they felt when they were informed to leave and saw how their home and neighborhood were completely demolished. In conclusion, the current planning regime not only continues the tradition of elitist planning, but also, in comparison, make residents the underdogs in urban development through the mentioned legal provisions.

\subsection{Land Management under Ethnic Federalism and Autonomous Urban Administrations}

One central component of the Ethiopian constitution is Ethnic Federalism. The constitution, in Article 39, has promulgated the right of each Nation, Nationality, and People of Ethiopia for self-determination, to establish self-government in the territory that it inhabits, and to equitable representation in state and Federal governments [40]. With Articles 47 and 49, the constitution declares nine Federal States and self-government right of residents in Addis Ababa, respectively [40]. Later on, in Proclamation No. 416/2004, Diredawa, a city in Southeast Ethiopia, is declared as an autonomous city government [57]. As it is mentioned in the introduction, these legal provisions celebrating ethnic identity, despite all the positive intentions, have become a source of conflict in managing cross-regional-boundary issues. So far, there are no obvious or genuine attempts to deal with potential conflicts in planning and managing land and other natural resources beyond regional boundaries and in particular peri-urban areas separated by regional political boundaries. With this in mind, the Federal Government and Addis Ababa City Administration prepared NUDSP and AAOSIDP, respectively. The later caused protests and violent riots, while the National Plan is in a limbo of meaninglessness. The next section discusses the content of these plans and highlights gaps and limitations, which have aggravated the existing conflicts among individuals, national, and local interests.

\subsubsection{National Urban Development Spatial Plan (NUDSP)}

Since 2005, the focus of development planning in Ethiopia has shifted from rural to urban. With the five years' development plan titled PASDEP (Plan for Accelerate and Sustained Development to End Poverty), the Federal Government has made cities the focus of development programmes [58]. Following that, in 2006, the first urban development policy was enacted and in 2008, and the urban planning proclamation, discussed in the above section, was promulgated $[59,60]$. The policy is a general framework that shows 
the paradigm shifts clearly. In its objectives, the policy highlights the importance of urban development to accelerate rural development and to support progress in sociocultural and democratic transformation. In addition, the urban planning proclamation provides for three level of planning: national urban development scheme, regional urban development plan, and urban plan. The NUDSP (National Urban Development Spatial Plan) is then an important instrument to implement the objectives of the policy and empowered through the proclamation 574/2008. NUDSP is the urban development component of the current development program, and it is a guideline to support future government and private investments all over the country [61].

In 2014, a French firm, Egis International, was commissioned with the preparation of national urban spatial plan by Ethiopian government [62]. The firm had prepared different scenarios with objectives focusing on development of secondary cities; reduction of urban-rural and regional disparities; establishing and strengthening networks of urban and service centers through development of logistic, road, and transportation systems; and developing strategies to exploit existing social, economic, natural, and infrastructural potentials. In addition, the scenarios made the use of demographic prospect of CSA (Central Statistical Authority in Ethiopia), energy sector prospects for the year 2037, prospects of African Development bank, industry development forecasts for 2025, and climate change and green economy prospects of 2030. The spatial plan views urban-rural linkage and cluster urban development as central in unlocking economic development in Ethiopia. The plan highlights that the urban-rural disparity and the primacy of Addis Ababa, the capital city, as key development challenges.

The urban-rural linkage is envisioned to be developed at two levels: center-metro region development and networking secondary and tertiary urban centers. The planning of the metro region is expected to create clear roles for different levels of urban centers and with that to improve access to market and services for the rural hinterland. The aim of developing and improving a network of secondary and tertiary urban centers is to strengthen the roles of these rural towns as service and market centers and to enhance urban agglomeration. Urban agglomeration is seen as a conducive environment for regional industrialization. At the same time, the development of regional industrialization supports the growth of regional economy with an impact on investment on road and transportation infrastructure and growth of livelihood opportunities.

The spatial plan takes seven existing and emerging agglomeration areas as urban clusters for future investments in urban and rural areas. The plan identifies three types of clusters:

- Metropolitan cluster/Addis Ababa metro cluster: this cluster integrates all types of urban services and economic sectors. The plan identified seven important cities, seventeen administrative districts at a maximum of $160 \mathrm{Km}$ distance from the capital city, and discussed the roles that these cities should play depending on ongoing and planned infrastructure, industrial, and service related projects.

- Secondary cities clusters: the plan uses seven important cities all over the country with a population of at least 150 thousand to develop urban clusters with different roles. These important urban centers, for instance Mekele in the North, Bahir Dar in Northwest, Diredawa in Southeast, and Jimma in the South are expected to facilitate urban development corridors linking important secondary and tertiary urban centers within their respective regions. In addition, the plan assumes that these growth poles will attract investments and become the destination of regional migration. Consequently, their role will affect the national urban growth pattern in reversing the primacy of Addis Ababa.

- Tertiary and oasis cities clusters: these are in most cases emerging agglomerations, which will play important roles in development of services and logistic in areas with relatively less urbanization and dominantly agro-pastoral potentials.

The intention of the plan is guiding urbanization in Ethiopia and reducing disparities in national and regional levels. However, most of the maps illustrating the proposals of the 
national plan, i.e., NUDSP, do not show state boundaries. Even the couple of plans that show faint lines of the politico-administrative boundaries in the current federal system do not indicate this in the legend. It is not clear, if the boundaries are purposely left out or if it is a technical error. However, for the tense regional relationship in Ethiopia, the absence of the boundaries is enough to raise suspicion and offend regional authorities. According to the informants in the MUDH, regional politicians had complained about the mandate of the federal government in making the decision, while the regions have the constitutional right to manage their land. The regional authorities find it inappropriate that social infrastructural components such as R\&D (research and development) and higher education facilities are planned for only couple of regions. In addition, the planning process has completely excluded the main stakeholders, i.e., the federal states. The authorities see the plan as evasion of the constitutional right of the federal states and fear that their region will be permanently fixed to particular type of development sectors, which in their eyes might be disadvantageous. For the legal enactment of the plan, it must be approved by the federal parliament. As a result, the annoyance on the absence of participation and fear of the results, the parliament declined to endorse it.

Indeed, the federal proclamation No. 574/2008 in Article 7 lists: (1) national urban development scheme, (2) regional urban development plan, and (3) urban plans [60]. One could argue about the difference of a scheme and a spatial plan. Nevertheless, there is no clarity in the legal provision with what is meant by scheme. Further, the definition and specification in the proclamation are only for the structure and local development plan [63]. Both these plans are in the third level of planning or are more local plans. Other important provision of proclamation No. 574/2008 (Article 55) is on the power and duties of the ministry. For instance, the article puts forward that the ministry has the responsibility to prepare the national urban development "scheme" in cooperation with concerned federal government and there is no mention of regional states or their role in the preparation of the national urban development scheme. Likewise, the structure plan manual prepared in 2012, in discussing the level of plans in Ethiopian planning system, only refers to "scheme" for the highest planning level, i.e., National Urban Development Scheme [63].

The findings show several problems in the NUDSP, which might have also contributed to the oppositions by the regional states and gaps in its conception and structure. For instance, it is not at all clear how regional states are expected to work on the implementation of trans-regional urban corridors and clusters. Indeed, the plan has neglected the existing and potential conflicts and challenges of preparing and implementing such kind of national plan within the context of ethnic federalism. This reminds us again of the old problem: planning by foreign consultants with probably no or limited knowledge on the politics and realities of ethnic federalism in Ethiopia.

From a conceptual perspective, some things are not clear. First, the plan is supposed to be a "spatial" urban plan. However, it does not explain how the national spatial plan could be only "urban" at all. There is no mention of the rural and agriculture development policy or if there are conflicts between the aim of the plan and different rural development strategies and existing land uses. Proposing clusters and urban development corridors in dominantly rural landscapes without considering these issues gives the impression that rural areas are just subcategories of urban centers and possible to plan from only urban perspectives. This leads us to the second gaps. The spatial plan ignores existing dual land management systems in the country. In Ethiopia, in general, there are urban focused land management policies, such as lease policy, while in rural area there are dominantly customary and other land tenure systems [27]. The NUDSP goes even further to recommend, superficially, what to do for developing rural areas without adequate assessment of sectoral strategies and programmes related to rural development [64]. In addition, important environmental issues are not at all mentioned. For instance, the plan neglects the management of forests and other natural resources transcending urban-rural and regional boundaries. 
In the section dedicated to ensure effective implementation [64], the plan lists institutes, agencies, and funds that should be established. Even though the idea is highly relevant for implementation, it is not clear on which facts these recommendations are based. For instance, there is no discussion on institutional gap and the necessity to establish the recommended organizations or agencies. The plan recommends the establishment of the Ethiopian Urban Planning Institute, Land Development Agency or Corporation, or Urban Development Agency and the likes to oversee and implement the plan. Howerver, it does not refer to existing structures such as National Planning Council, National Planning Commission and Ministry of Environment, or Forest and Climate Change of Ethiopia. While the urban planning law [60] clearly defines the role of the MUDH in overseeing the implementation of the National Urban Development Scheme, it is a dilemma why it recommends new organizations and refrains from indicating the role of the existing ones in implementing the plan. This again leads to the question of whether the consultant investigated the existing institutional set-up and found gaps for implementing the proposals. The interview with experts of planning and policy issue in the MUDH did not provide clarity if this problem emanated from the side of the ministry (MUDH) in executing its responsibility of commissioning the project and endorsing the spatial plan. The plan also does not mention AACSP (Addis Ababa City Structure Plan) and the integrated regional plan (AAOSIDP), especially with its uncanny resemblance to the proposals of AAOSIDP, which had been presented for public discussion in 2014 (Figure 5). Interview with the planners involved in the preparation of AAOSIDP revealed that they were aware of the NUDSP but lacked detailed information on the proposal. However, they confirmed cooperation with Lyon Town Planning Agency in the preparation of AAOSIDP. Lack of reference to AAOSIDP is intriguing, as the NUDSP was developed later on.
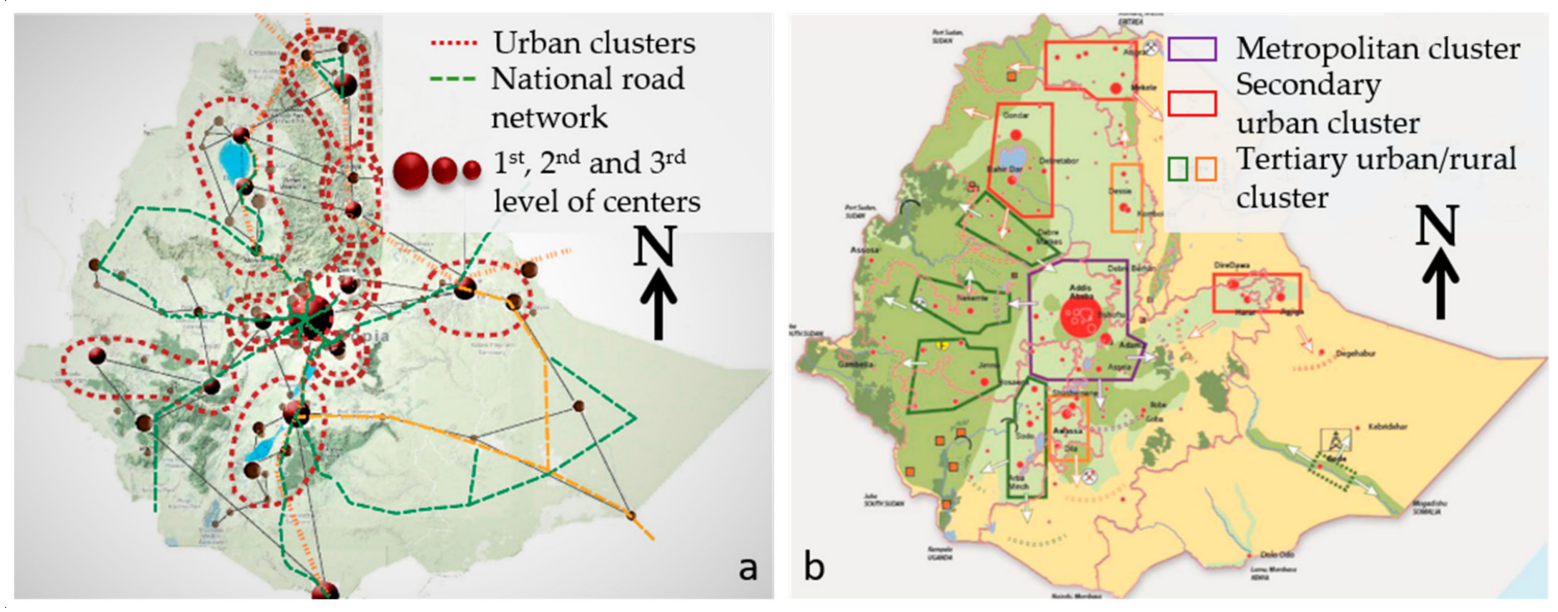

Figure 5. Urban clusters as proposed by (a) AAOSIDP 2006 [65] and (b) NUDSP 2016 [66].

\subsubsection{Addis Ababa and Surrounding Oromia Integrated Development Plan (AAOSIDP)}

Since the 1986 Master Plan, there have been couple of attempts to integrate the urban plan with the metropolitan one without success. The interviews with planners, who participated in the two former planning of the city, i.e., in 1986 and 2002, indicate two main reasons for this lack of success. The first and persisting reason is the fear that Addis Ababa, using the regional plan, could officially extend its boundary at the cost of land in Oromia Regional Government (ORG). The second one was that there was no legal and institutional provision to prepare and implement a plan that transcends regional and urbanrural boundaries. The urban planning proclamation of 2008 was enacted hoping to fill this gap and facilitate cross-boundary planning. This was the context in which the project office for Addis Ababa and the surrounding Oromia integrated development plan (AAOSIDP) was established. The project had a supervisory board led by Addis Ababa's mayor and Oromia State Deputy President. In addition, the project was supported by Technical 
Advisory Committee and Think-Tank groups who assisted in developing concepts and provided feedbacks on the planning process and intermediate results (interview, [65]). The project office team was composed of experts from Addis Ababa and ORG [interview]. However, from the beginning, the relationship among planners who were working for the project office in Addis Ababa and the ones working in Oromia Urban Development and Housing Bureau was not smooth. The informants believe that their colleagues from ORG resented the fact that not all the staff in Addis Ababa were Oromo and/or do not speak the Oromo language.

The development plan initially had two major components: regional plan and structure plan. The structure plan was mainly concerned with Addis Ababa, while the regional one included the surrounding 36 urban centers and seventeen districts in ORG. In addition, analyzing the national prospects of urbanization, it proposes a framework for a national urban system and uses the framework to define the planning area in relation to other existing and potential urban agglomeration areas in the country [65]. Despite the name, i.e., integrated regional plan, it is composed of three different level of plans as provided by urban planning proclamation. These different levels of plans correspond to the national urban development scheme, regional, and urban plan in the urban planning proclamation [60]. As it is discussed in the above section, the national urban development scheme in this plan seems to be adopted by NUDSP [66].

The regional plan identifies existing and potential development corridors, basing the analysis on national and regional dynamics of urbanization and planned capital projects. These corridors are the key components of the framework for regional infrastructure development such as transportation and logistics [65]. Eighty-five percent of the integrated planning area is rural. Consequently, urban-rural linkage is considered as one of the key planning components. In addition, urban-rural linkage is addressed through other planning components, such as hierarchy of regional centers. This component defines hierarchy of selected urban centers and their respective roles. Consequently, tertiary and other district and small centers are considered as key rural service centers, where the development of markets, social services, and transportation hubs should be encouraged $[65,66]$. The integrated regional plan advocates a mixed land use plan and specifies strategic development areas. These strategic development areas are selected in terms of their importance as commercial areas, public transportation hubs, adequacy for developing industrial villages and dry ports, and availability of special natural and infrastructural resources.

The integrated regional plan [65] is prepared on the background of existing political conflicts on the question of Addis Ababa's autonomous status and the historical problem on land right in Ethiopia [67]. In addition, there was widespread discontent and frustration on the side of farming communities in the periphery of Addis Ababa on eviction of farmers and conversion of farming land for urban development [informants; Table 2]. Hence, from the beginning, the planning process was charged by historical conflicts on the status of Addis Ababa and fear of its aim. Informants, who were part of the planning team, complained that they would have preferred to limit the extent of the planning within the boundaries of Addis Ababa. The planning staff in Addis Ababa highlighted that they were aware of the resistance against the initiative to prepare a joint regional plan from the start. However, the political decision by both Addis Ababa and ORG had underestimated the discontent and opposition on the joint planning.

Beyond fear of eviction and questions on trans-boundary planning, the main problem lies with the ambiguous constitutional provision on the autonomy of Addis Ababa that perpetuates "special interest" of ORG, which had suddenly grown to ownership. Addis Ababa is established in 1896 as capital city on an area, which was at the time inhabited by Oromo pastoralists [68]. On the other hand, the 1995 Ethiopian constitution, which declared ethnic federalism, provided Addis Ababa an autonomous status, while at the same time stating that the Oromia Regional Government's interest would be protected [40]. This vague provision of the constitution has left Addis Ababa and its residents in limbo and made Oromo elites question the autonomous status of the city. Despite the fact that 
the planning project is endorsed by the ODP (Oromo Democratic Party), Addis Ababa is administered by the same party, the rhetoric was dominated by the "Addis Ababa Structure Plan" or, as it is popularly called, "Addis Ababa Master Plan", and the allegations that the plan is a pretext to encroach on the territory of ORG [29]. So far, it is not clear if the attempt has been the result of political naivety, which had failed to see the extent of the problem. On the other hand, interviews with residents in Addis Ababa and farmers in peri-urban areas reveal that individually, everyone fears any kind of urban plan. It does not matter, where they live, the fear is the same. If an urban plan indicates the area of their neighbourhood or farmstead, urban and rural residents have little legal foundation they can rely on to resist. As it is discussed in Section 3.2, legal enactments such as Proclamation No. 455/2005, prohibit the right to sue urban or regional administrations [55]. Consequently, individual urban and rural residents do not trust the objective of the plan is genuine, associating it primarily as a tool for land grabbing. This and politically motivated conflicts might have fuelled the strong opposition and protests, which had lasted more than two years since the plan was broadcasted in 2014. On January 12, 2016, after persisting protests and several causalities, ODP announced the cancellation of the integrated regional plan [29]. Indeed, this plan has triggered nationwide protests, which ended the 27 years' domination of TPLF (Tigray People's Liberation Front) in the Ethiopian Government.

Finally, Addis Ababa's structure plan was prepared without any mention and framework that also takes into consideration developments beyond its administrative boundary [66]. This is indeed a disaster for sustainable land and resource management. To date, there are no clear framework and coordination between Addis Ababa and the ORG in the management of, for instance, green and waterbodies and the supply of clean water in peri-urban areas. Both city and regional administration authorities need cooperation in managing cross-boundary issues, protection of natural resources, and flow of goods and people. In addition, several urban and rural settlements in Oromia Region depend on services located in Addis Ababa. In fact, the districts of ORG around the peri-urban areas of Addis Ababa are already suffering from rising land speculation. This has led to destruction of natural forests and informal land transactions (Figures 2 and 6).

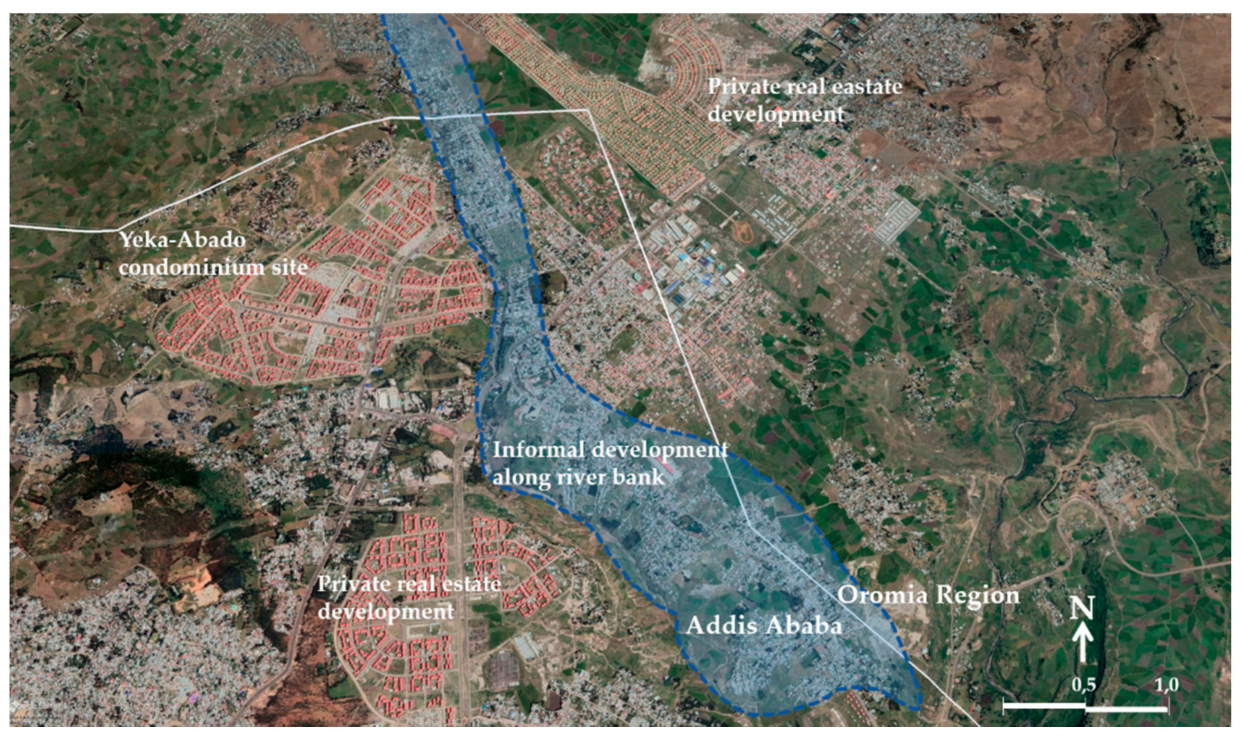

Figure 6. Urban development along Oromia Region and Addis Ababa boundary. Own construct based on Google Earth 2020.

\section{Discussion}

Cross-boundary land governance within ethnic federalism is a complex and politicized process. Land governance along federal boundaries requires spatial plans, which combine the socioeconomic and environmental aims of the federal regions sharing boundaries. At the same time, these aims should respond to the actual and future needs of the wider public. 
Spatial planning is good enough depending on the institutional framework in which it is anchored. In addition, the quality and efficiency of planning depend on the policy framework in which planning goals are developed and how planners are trained. In Ethiopia, urban plans from their conception are based on borrowed concepts. Firstly, it totally neglects local values of urban tradition. Secondly, it ignores socio-economic reality of urban residents. Third, the current rhetoric of slum or informal settlements dictates how urban administrations and national governments deal with urban development $[9,12,13,17,18,20]$. Within this context, slum reduction is equated with demolishing of informal settlements. However, informal settlements are not only slums, but also housing forms, corresponding to the socioeconomic and historical realities of their residents. Fourth, the reality of ethnic federalism and the challenge for cross-boundary land governance is not properly addressed. Despite the fact that spatial developments are fluid, transcending political boundaries, real land governance of such areas takes places in different and conflicting parallel regional institutional systems. The case of NUDSP and AAOSIDP shows that cross boundary planning without integrated land governance system is a source of conflict rather than a solution. In addition, within a semi-authoritarian system of government, there are limited options for citizens, in particular for those socially and economically weak, to influence planning and legal provisions. Residents of urban and rural areas in Ethiopia know from their personal and communal experience that plans are there to take away their right to live and work in inner cities and peri-urban areas. Indeed, throughout the short history of urban planning in Ethiopia, interests of the residents have never been the concern. In addition, laws and bylaws, such as Proclamation no. 455/2005 are enacted not to protect the residents, but to take away constitutional and civil rights [40,55]. This has made residents, in particular the poor, hostile toward any kind of planning. In the age of ethnic federalism and divided land governance along ethnic lines, this hard feeling has become a source of manipulation for populist politics. Indeed, in a context where poverty is widespread and conflicts over resources are intermingled with ethnic ones, planning induces and reinforces irreconcilable rationalities $[11,22,23]$.

Both plans, i.e., NUDSP and the integrated development plan of Addis Ababa and Oromia Region, are top down. Both plans show that people who are affected by the plan are not consulted and that planners do not ask the consequences on poor families and farmers that might be affected by the plans. Even though there might be some technical logic and useful ideas, which might, in some way, make positive impacts on the residents, the plans are overshadowed by their shortcomings, i.e., being top-down, elitist, and unrealistic for the actual land governance system and ethnic politics. This is especially bitter for residents, in a context of public land ownership system without individual or communal tenure security. Indeed, both plans are very concerned about economic growth and have a naive expectation that economic growth will bring equity [64]. The plans assume that the outcomes are rational and therefore will benefit the public. One can also sense a touch of arrogance and naivety that regional authorities and citizens accept, respect, and play their part in the implementation of short and long term aims of the plans [21]. Even though experiences showed that technocratic planning had several times failed, the plans rely on the capacity of the government to set-up implementing organizations and institutional infrastructure on the top of the federal regions. This is in particular obvious in NUDSP. The report has dedicated no section for institutional and historical context of the country in general and in particular, the role of federal regions and their planning and land governance plans. Additionally, issues of environmental protection and sustainable sociospatial growth are fully neglected (Figures 5 and 6). The authorities, who commissioned the plans, fail to see the consequences on the urban and rural communities. On the other hand, the plans, in particular AASOID, provoked the anger of the wider population, who feel threatened by these plans. In this regard, urban planning, since its introduction, has not changed at all, as the attitude of political elite remains "we know what is good for you". At last, the failure of planning has also shown a drastic impact on the management of peri-urban areas and in particular on natural resources [20,21]. 


\section{Conclusions}

In the face of rapid urbanization, spatial planning is indispensable. In fact, from its conception, it is a societal action to deal with problems at hand and future challenges [1]. Yet, planning without adequate governance, institutional, policy, and regulation framework could end up in producing inequality and marginalization of disadvantaged groups [22]. Additionally, spatial planning should be anchored in legitimate land governance system, which ensures, first, the integration of the planning process within the existing land governance system; secondly, participation of stakeholders; and third, its implementation. This was one of the principal gaps observed in both analyzed plans. The plans were prepared in absence of corresponding land governance system managing cross-boundary issues. The results also show how decades of elite centered and top-down planning have nursed distrust and animosity toward planning and planning authorities.

The paper calls a radical reform of the policy and legal framework, guiding spatial planning in Ethiopia. For this purpose, the paper outline the following key recommendations:

- Review of proclamations to restore rights of citizens to protect their properties: Article 15(2) of Proclamation No. 455/2005 for expropriation of land for public should be revoked to permit citizens to defend their rights to keep their homestead, neighborhood, and/or livelihoods. Otherwise, residents have no means to defend unjust planning interventions. Articles 4 and 16 of Proclamation No. 624/2009 provide for planned urban centers and economic growth. These provisions should be corrected to include the importance of traditional and "unplanned" settlements, as they are officially called, to protect the way of life of most of urban residents. These settlements are the result of everyday urbanization and reflect the socioeconomic reality of their residents. In addition, economic growth should not be the whole purpose of laws and urban plans. Hence, Article 16 should include socio-cultural development and just city principles. The role of the government and spatial plans, in contrast to a developer, is to also ensure social welfare [2]. Legal provision should facilitate investment but should not be a carte blanche for capital accumulation and to produce images supposedly representing good cities $[2,8,17,18,20]$. Otherwise, such legal provisions will continue inciting conflicts and violent opposition toward spatial plans.

- Participation of stakeholders and the role of local, regional, and national planning agents: Cross-boundary planning, whether on the regional or national level, should be lead and guided by concerned regional authorities and actors representing residents that might be affected by the plan and with a stake in the area in focus. The aim of planning should be sustainable socio-economic growth. Sustainable socio-economic growth is not possible if citizens are excluded from the decision making process and resource distribution. Although economic growth is important, without proper focus on the protection of individual and communal rights of property rights and natural resources, planning cannot bring sustained socio-economic growth [5]. As Bertolini [69] noted, spatial planning should empower residents to get a voice and express themselves. The processes of planning should be a project of diverse social groups and civil societies advocating for sustainable socio-spatial development. Therefore, the NUDSP and AAOSIDP should be revised by a joint planning team composed of local, regional, and national planning authorities and publicly presented not only to inform but also to open access for feedbacks coming for different perspectives. In particular, the aims and contents of the NUDSP should be revised, taking into consideration the spatial development aims of federal regions and urban authorities and existing federal and regional institutional actors involved in spatial planning and management of cross-boundary infrastructural and natural assets.

- Social and institutional preconditions for spatial planning projects: The results of this paper show spatial plans were prepared without prior socio-political impact assessment. Therefore, impact assessment of possible land uses changes along urban and regional boundaries and in inner cities. The assessment should include the analysis of actors (grassroots, civil societies, and planning agents) in a potential 
planning area, socio-political consequences as a result of changes in land value and use, and institutional and organizational gaps to facilitate the participation of key actors and joint action. The result of such assessment should facilitate and guide a tailor-made spatial planning concept.

Funding: This research was funded by German Education and Research Ministry (BMBF), grant number "01DG17014".

Data Availability Statement: Not applicable.

Acknowledgments: I am indebted to several people in Addis Ababa who gave me their time, made documents available, and helped me to get informants. In particular, I would like to acknowledge the support of my friends and former colleagues Lia G.Mariam and Mathewos Bekele; my siblings Ayele, Selamawit, and Tazanesh Alem; informants Genet Gebreyesuss, Abuye Anley, and Yitbarek Mengiste; residents in Jemu, Lideta, and Bole-Bulbula condominium; and members of self-help farmers initiatives in Bole-Bulbula.

Conflicts of Interest: The funders had no role in the design of the study; in the collection, analyses, or interpretation of data; in the writing of the manuscript; or in the decision to publish the results.

\section{References}

1. United Nations Human Settlements Programme. Planning Sustainable Cities: Global Report on Human Settlements 2009; Earthscan: London, UK, 2009.

2. Knaap, G.J.; Hopkins, L.D.; Donaghy, K.P. Do Plans Matter? A Game-Theoretic Model for Examining the Logic and Effects of Land Use Planning. J. Plan. Educ. Res. 1998, 18, 25-34. [CrossRef]

3. Friedmann, J. Planning Theory Revisited. Eur. Plan. Stud. 1998, 6, 245-253. [CrossRef]

4. Healey, P. Planning Theory: The Good City and Its Governance. In International Encyclopedia of the Social \& Behavioral Sciences; Elsevier: Amsterdam, The Netherlands, 2015; pp. 202-207. [CrossRef]

5. Healey, P. The Universal and the Contingent: Some Reflections on the Transnational Flow of Planning Ideas and Practices. Plan. Theory 2012, 11, 188-207. [CrossRef]

6. Allmendinger, P. Planning Theory, 2nd ed.; Palgrve Macmillan: New York, NY, USA, 2009.

7. Watson, V. Seeing from the South: Refocusing Urban Planning on the Globe's Central Urban Issues. UrbanStudies 2009, 46, 2259-2275. [CrossRef]

8. Roy, A. Slumdog Cities: Rethinking Subaltern Urbanism: Rethinking Subaltern Urbanism. Int. J. Urban Reg. Res. 2011, 35, 223-238. [CrossRef]

9. Connell, R. Using Southern Theory: Decolonizing Social Thought in Theory, Research and Application. Plan. Theory 2014, 13, 210-223. [CrossRef]

10. Knieling, J.; Othengrafen, F. Planning Culture-A Concept to Explain the Evolution of Planning Policies and Processes in Europe? Eur. Plan. Stud. 2015, 23, 2133-2147. [CrossRef]

11. De Satgé, R.; Watson, V. Urban Planning in the Global South: Conflicting Rationalities in Contested Urban Space; Springer International Publishing: Cham, Switzerland, 2018.

12. Diouf, M.; Fredericks, R. Introduction: Decolonizing Urban Theory. In The Arts of Citizenship in African Cities; Diouf, M., Fredericks, R., Eds.; Palgrave Macmillan US: New York, NY, USA, 2014; pp. 1-23. [CrossRef]

13. Watson, V. Changing Planning Law in Africa: An Introduction to the Issue. Urban Forum 2011, 22, 203-208. [CrossRef]

14. Wesely, J.; Allen, A. De-Colonising Planning Education? Exploring the Geographies of Urban Planning Education Networks. Urban Plan. 2019, 4, 139-151. [CrossRef]

15. World Population Prospects 2019; United Nations: New York, NY, USA, 2019; Volume 2.

16. PSUP. Slum Almanac 2015/2016. Tracking Improvement in the Lives of Slum Dwellers; UN-Habitat: Nairobi, Kenya, 2016.

17. Watson, V. African Urban Fantasies: Dreams or Nightmares? Environ. Urban. 2014, 26, 215-231. [CrossRef]

18. Cain, A. African Urban Fantasies: Past Lessons and Emerging Realities. Environ. Urban. 2014, 26, 561-567. [CrossRef]

19. Watson, V.; Odendaal, N. Changing Planning Education in Africa: The Role of the Association of African Planning Schools. J. Plan. Educ. Res. 2013, 33, 96-107. [CrossRef]

20. Andersen, J.E.; Jenkins, P.; Nielsen, M. Who Plans the African City? A Case Study of Maputo: Part 1—the Structural Context. Int. Dev. Plan. Rev. 2015, 37, 329-350. [CrossRef]

21. Watson, V. Conflicting Rationalities: Implications for Planning Theory and Ethics. Plan. Theory Pract. 2003, 4, 395-407. [CrossRef]

22. Yiftachel, O. Planning and Social Control: Exploring the Dark Side. J. Plan. Lit. 1998, 12, 395-406. [CrossRef]

23. Yiftachel, O. Planning as Control: Policy and Resistance in a Deeply Divided Society. Prog. Plan. 1995, 44, 115. [CrossRef]

24. Watson, V. Deep Difference: Diversity, Planning and Ethics. Plan. Theory 2006, 5, 31-50. [CrossRef]

25. Yiftachel, O. Essay: Re-Engaging Planning Theory? Towards 'South-Eastern' Perspectives. Plan. Theory 2006, 5, 211-222. [CrossRef] 
26. Alemu, G.T. Land Expropriation and Compensation Payment in Ethiopia: Review. J. Econ. Sustain. Dev. 2015, 6, 93-97.

27. Lavers, T. Responding to Land-Based Conflict in Ethiopia: The Land Rights of Ethnic Minorities under Federalism. Afr. Aff. 2018, 117, 462-484. [CrossRef]

28. BBC. Ethiopia Cancels Addis Ababa Master Plan after Oromo Protests. Available online: https://www.bbc.com/news/worldafrica-35300471 (accessed on 30 August 2019).

29. Muindi, M. Why Ethiopia is Making a Historic 'Master Plan' Uturn. Available online: https://www.bbc.com/news/worldafrica-35325536 (accessed on 30 August 2019).

30. Denzin, N.K.; Lincoln, Y.S. Introduction: The Discipline and Practice of Qualitative Research. In Handbook of Qualitative Research; Denzin, N.K., Lincoln, Y.S., Eds.; Sage Publications Thousand Oaks: California, CA, USA, 2005; pp. 1-32.

31. Flick, U.; von Kardorff, E.; Steinke, I. Was ist qualitative Forschung? Einleitung und Überblick. In Qualitative Forschung: ein Handbuch; Flick, U., von Kardorff, E., Steinke, I., Eds.; Rororo Rowohlts Enzyklopädie; rowohlts enzyklopädie im Rowohlt Taschenbuch Verlag: Reinbek, Germany, 2017; pp. 13-29.

32. Crewett, W.; Korf, B. Ethiopia: Reforming Land Tenure. Rev. Afr. Polit. Econ. 2008, 35, 203-220. [CrossRef]

33. Rahmato, D. Land to Investors: Large Scale Land Transfers in Ethiopia; Forum for Social Studies: Addis Ababa, Ethiopia, 2011.

34. Böll, V. Donald Crummey: Land and Society in the Christian Kingdom of Ethiopia. From the Thirteenth to the Twentieth Century. Aethiopica 2013, 5, 244-248. [CrossRef]

35. Pankhurst, R. State and Land in Ethiopian History.; The Institute of Ethiopian Studies: Addis Ababa, Ethiopia, 1966.

36. Proclamation No. 31 of 1975. A Proclamation to Provide for Public Ownership of Rural Lands; The Provisional Military Administrative Council: Addis Ababa, Ethiopia, 1975.

37. Proclamation No. 47 of 1975. A Proclamation to Provide for Government Ownership of Urban Lands and Extra Urban Houses; The Provisional Military Administrative Council: Addis Ababa, Ethiopia, 1975; pp. 200-215.

38. Ambaye, D.W. Land Rights in Ethiopia: Ownership, Equity and Liberty in Land Use Rights. In Proceedings of the FIG Working Week, Rome Italy, 6-10 May 2012; FIG: Rome, Italy, 2012.

39. Gebre, S. Urban Land Issues and Policies in Ethiopia. In Land Tenure and Land Policy in Ethiopia; Rahmato, D., Ed.; University of Trondheim: Trondheim, Norway, 1994; pp. 278-302.

40. Proclamation No. 1/1995, Constitution of Federal Democratic Republic of Ethiopia; FDRE: Addis Ababa, Ethiopia, $1995 ;$ pp. 1-38.

41. Proclamation No. 80/1993. Urban Lands Lease Holding Proclamation; The Transitional Government of Ethiopia: Addis Ababa, Ethiopia, 1993.

42. Alem, G. Traditional Use and Meaning of Urban Spaces: The Case of Highland Towns of North Ethiopia; Schriftenreihe ex Architectura; Kovač: Hamburg, Germany, 2011.

43. Anteneh, L.A. Untersuchung des Standes der Stadtentwicklung in Äthiopien. Ph.D. Thesis, Hochschule für Architektur und Bauwesen Weimar, Weimar, Germany, 1995.

44. Ashenafi, S. Legal and Institutional Aspects of Municipal Administration in Ethiopia; Ministry of Works and Urban Development: Addis Ababa, Ethiopia, 1996.

45. Consolidated Ethiopian Laws (1942 to 1961 EC); Faculty of Law, Hilesilasie I University, Central Press: Adis Ababa, Ethiopia, 1965.

46. Kropp, M. The Ser'ata Gebr. A Mirror View Dly. Life Ethiop. R. Court. Middle Ages. Northeast Afr. Stud. 1988, 10, $219-229$.

47. Scholler, H. Ethiopian Constitutional and Legal Development; R. Köppe: Köln, Germany, 2005.

48. ORAAMP. Executive Summary of the Revised Addis Ababa Master Plan; Addis Ababa City Administration: Addis Ababa, Ethiopia, 2002; p. 64.

49. Antonsich, M. Signs of Power: Fascist Urban Iconographies in Ethiopia (1930s-1940s). GeoJournal 2001, 52, 325-338. [CrossRef]

50. Giorgis, G.T. Features of Urban Centres in Ethiopia and Policy Options for Upgrading the Urban Setting. In Proceedings of the Workshop on Regional Development Planning and Policy Issues; UNDP: Nazreth, Israel, 1995.

51. Kale, C.B.; Worku, H.; Yalew, T. Widening Perspectives and Improving Capacities Central Task for Planning of Our Towns. In Proceedings of the 3rd National Conference on Urban Planning and Related Issues; Nazareth, Ethiopia; National Urban Planning Institute: Addis Ababa, Ethiopia, 2003.

52. Ahderom, T. Basic Planning Principles and Objectives Taken in the Preparation of the Addis Ababa Master Plan, Past and Present. In Proceedings of the International Symposium on the Centenary of Addis Ababa, Addis Ababa-Asmara, Ethiopia, 24-25 January 1987; Institute of Ethiopian Studies: Addis Ababa, Ethiopia, 1987; pp. 247-268.

53. Fuller, M. Wherever You Go, There You Are: Fascist Plans for the Colonial City of Addis Ababa and the Colonizing Suburb of EUR '42. J. Contemp. Hist. 1996, 31, 397-418. [CrossRef]

54. Siraje, M. Land Governance in Urban Renewal Induced Eviction and Relocation in Inner City Areas of Addis Ababa, Ethiopia. Ph.D. Thesis, Addis Ababa University, Addis Ababa, Ethiopia, 2006.

55. Proclamation No. 455/2005, Expropriation of Landholdings for Public Purposes and Payment of Compensation; FDRE: Addis Ababa, Ethiopia, 2005; pp. 3124-3132.

56. Ethiopian Building Proclamation No. 624/2009; FDRE: Addis Ababa, Ethiopia, 2009; pp. 4673-4702.

57. Proclamation No. 416/2004, The Diredawa Administration Charter; FDRE: Addis Ababa, Ethiopia, 2004; pp. $2808-2837$.

58. Plan for Accelerated and Sustained Development to End Poverty (2005/06-2009/10): Urban Development E Construction Industry Component of PASDEP; Ministry of Finance and Economic Development (MoFED): Addis Ababa, Ethiopia, 2006 ; p. 40.

59. MWUD. Urban Development Policy; MWUD: Addis Ababa, Ethiopia, 1998. 
60. Urban Planning Proclamation No. 574/2008; FDRE: Addis Ababa, Ethiopia, 2008; pp. 4067-4085.

61. Growth and Transformation Plan II (GTP II); National Development Plan; National Planning Commission: Addis Ababa, Ethiopia, 2016.

62. Assefa, S. French Firms Recommend Several Urban Centres for Ethiopia. Available online: https://addisfortune.net/articles/ french-firms-recommend-several-urban-centres-for-ethiopia/ (accessed on 4 September 2019).

63. MWUDEC. Structure Plan Manual; Revised Version; MWUDEC: Addis Ababa, Ethiopia, 2006.

64. Egis International association; IAU-IdF; Urba Lyon. National Urban Development Spatial Plan (NUDSP). Ethiopia's Urban Development Scenarios; Final Report; Ministry of Urban Development \& Housing: Addis Ababa, Ethiopia, 2016.

65. AACPPO. Addis Ababa City Structure Plan. Draft Final Summary Report (2017-2027); Addis Ababa City Administration: Addis Ababa, Ethiopia, 2017.

66. AAOSIDPO. Addis Ababa and Oromia Special Zone Joint Integrated Development Plan; Unpublished Report; Addis Ababa City Administration and Oromia Federal Region: Addis Ababa, Ethiopia, 2006.

67. Gidada, N.A. Tragic Consequence of the 10th Addis Ababa Integrated Development Master Plan. Aiga Forum 2014, 1-10. Available online: https: / / ethiopoint.com/a-tragic-consequence-of-the-10th-a-a-integrated-development-master-plan-warning-for-thefuture-by-dr-negaso-gidada/ (accessed on 30 August 2019).

68. Tufa, D. Historical Development of Addis Ababa: Plans and Realities. JES 2008, 41, 27-59.

69. Bertolini, L. The Dream of Planning. Plan. Theory Pract. 2009, 10, 309-313. [CrossRef] 